III. Descriptions of some new Species of Hemipterous Insects belonging to the Tribe Scutata. By W. S. Dallas, Esq., F.L.S.

[Read 2nd February, 1852.]

Mr principal object in the present paper is to publish descriptions of various species of Hemiptera, belonging to some of the smaller genera proposed or adopted by me in the first part of the Catalogue of Hemipterous Insects contained in the Collection of the British Museum.

Most of these insects are in my own collection; for two of them I am indebted to the kindness of Mr. Westwood, and one is unique in the collection of this Society.

\author{
Family ASOPIDÆ. \\ Genus Oplomus, Spin. \\ Oplomus elongatus, n. s. (Pl. I. fig. 1.)
}

O. elongatus, cæruleus, virescenti-nitens, punctatus; elytrorum corio opaco; abdominis maculis 3 spinaque basali, femoribus omnibus tibiisque posticis et intermediis fulvis; geniculis, tibiis anticis totis, alterisque apice, tarsis, antennis rostroque nigris. 8 .

Long. lin. $5 \frac{1}{2}$ (m. 0.012).

Hab. in Brasilia? In Mr. Westwood's collection.

Very elongate, deep blue, shining, tinged with green. Head, above, rather thickly punctured, but with two smooth longitudinal bands on the vertex between the ocelli; beneath thickly and finely p! nctured. Eyes brown; ocelli yellow. Antennæ black, clothed with a pale pubescence; basal joint tinged with blue. Rostrum pitchy black, becoming pitchy towards the apex. Pronotum with the lateral margins waved, the lateral angles very slightly prominent; the surface convex, rather thickly and finely punctured, with a narrow smooth line down the centre. Scutellum rather sparingly and finely punctured at the base; the apical portion with a smooth, impunctate, raised line down the middle, on each side of which the surface is very thickly and finely punctured; the lateral margins thickly and finely punctured, leaving a narrow impunctate space on each side between the margin and the band of punctures which accompanies the central raised line. Breast thickly and finely punctured, with a smooth space on each side of the medipectus; 
the posterior margin of the medipectus, and the margins of the orifice of the odoriferous apparatus, black; mesosternum with a slight yellow keel. Coxæ brown; thighs and trochanters orange, the former with their apices blackish; anterior tibiæ violet black, shining, sparingly punctured; intermediate and posterior tibiæ orange, blackish at the base, violet black at the apex, finely pubescent ; tarsi black, tinged with violet, pubescent; claws reddish orange. Elytra with the coriaceous portion deep blue black, opaque, very faintly and not thickly punctured; the outer margin shining, with two rows of coarse punctures; apical margin smooth and shining; membrane brownish violet, shining. Margins of the abdomen very thickly and minutely punctured. Abdomen beneath rather thickly and finely punctured on the sides; disc smooth, with three large orange spots, placed on the third, fourth and fifth segments; basal spine orange, reaching the intermediate coxæ.

This insect is distinguished from all the species of Oplomus hitherto described, by its very elongate form, and the prominence of the lateral angles of its thorax; in other respects, however, it agrees precisely with the other species of that genus.

\section{Family SCIOCORIDÆ.}

\section{Genus Sciocoris, Fall.}

The genus Sciocoris appears to be peculiar to the eastern hemisphere, throughout which it is pretty generally distributed, species being found in the three old continents, in the eastern archipelago, and in Australia. Of the typical group of the genus (or Sciocoris prop.), however, including $S$. umbrinus and its immediate allies, no Australian species has hitherto, as far as $\mathrm{I}$ am aware, been described. This want will be supplied by the present species, for which I propose the name of-

Sciocoris australis, n. s. (Pl. I. fig. 2.)

S. pallidus, fusco-punctatus; capite subelongato, lineis 2 fuscis approximatis ; scutello basi utrinque vitta parva albida; abdominis marginibus nigro-maculatis, ventre lineis 2 e punctis fuscis; antennis tarsisque apice nigris. + .

Long. lin. 3 (m. 0.006).

Hab. in Novæ Hollandiæ parte Australiore. In my own collection.

Ovate. Head longer than broad, with the lateral margins sinuated in front of the eyes; above pale yellow, thickly and finely 
punctured, with the lateral margins brownish, and two approximated brown longitudinal lines converging in front, running from base to apex; beneath testaceous, rather thickly punctured. Eyes black. Antennæ with the three first joints pale brown, the second and third joints about equal in length; fourth and fifth joints black, fourth longer than the preceding, fifth longer than the fourth. Rostrum brown, becoming black at the apex. Pronotum testaceous, rather thickly and finely punctured with brown. Scutellum rather narrow, elongate, with the sides nearly parallel, very slightly narrowed towards the apex; testaceous, finely punctured with brown, thickly at the base and on the sides, more sparingly on the disc; with a small black impression in each basal angle, and within this on each side a small, slightly elevated, impunctate whitish spot, from which a slightly elevated, impunctate line runs towards the apex of the scutellum, which bears a small brown spot. Breast testaceous, rather thickly punctured, the punctures of various sizes, and either brown or colourless; postpectus with a large dull yellowish patch, punctured with brown, on each side at the orifice of the odoriferous apparatus. Legs testaceous, clothed with shortish hairs; tarsi with the apical joint and the tips of the claws pitchy black. Elytra with the coriaceous portion pale testaceous, thickly and finely punctured with brown, with a double row of larger brown punctures parallel to the suture of the clavus, and two longitudinal impunctate lines on the apical portion; the membrane opaque, brownish, with brown nervures. Projecting margins of the abdomen pale testaceous, sparingly and finely punctured with brown, with a small black spot at the junction of each segment. Abdomen beneath yellowish testaceous, thickly covered with very fine pale brown points, and with a longitudinal band of dark brown points on each side, considerably within the stigmata; stigmata black.

\section{Genus Mecidea, Dall.}

It may not be out of place to mention here, that the genus Cerataulax, proposed by M. Victor Signoret at p. 335 of the last volume of the Annales de la Sociête Entomologique de France, is identical with the above-named genus; the species described by him being, however, quite distinct from both those previously described by me in the British Museum Catalogue. The distinctive characters of the three species are subjoined. 
* Antennarum articulo secundo tertio multo longiori.

1. Mecidea quadrivittata.

Cerataulax quadrivittatus, Signoret, Ann. Soc. Ent. Fr. 2 me ser., ix. 336, pl. 10 , f. $9 \& 9$ a.

M. albida, supra fusco-punctatissima; linea media thoracis et scutelli, thoracis linea utrinque marginibusque elytrorum albidis ; corpore subtus utrinque fascia longitudinali e punctis fuscis; antennis fuscis. $\$$.

Long. lin. 5-6 (m. 0.011-0.013).

Hab. in Insula Mauritius. In Mr. Westwood's and M. Signoret's collections.

\section{Mecidea Indica.}

Dall. Cat. Hem. 139. 1. Pl. 3, fig. 3.

M. pallide testacea, punctatissima, linea media thoracis et scutelli impunctata; antennis obscurioribus. $\delta$ \&.

Long. lin. 5 (m. 0.011).

$\mathrm{Hab}$. in India Orientali. In the collections of the British Museum and of Mr. Saunders.

$\uparrow$ Antennarum articulis secundo et tertio longitudine fere æqualibus.

3. Mecidea linearis. Dall. Cat. Hem. 139. 2.

M. griseo-lutea, fusco-punctata ; membrana hyalina ; corpore subtus utrinque fascia longitudinali fusca. $\hat{\text { of }}$

Long. lin. $4 \frac{1}{2}$ (m. 0.009).

Hab. ? In the collection of the British Museum.

Genus Ednus, Dall.

I have proposed (British Museum Catalogue of Hemiptera, p. 144), the formation of a genus under this name, for the reception of a species of the family Sciocorida, distinguished by the large size of its scutellum, which reaches nearly to the apex of the body, and thus gives it a considerable resemblance to some members of the Scutelleroid group, especially the Podopida. I have now to lay before the Society the description of a second species of the genus, which still more closely resembles the Podopidae in its general form, and might easily be mistaken for a 
Podops at the first glance. The structure of the elytra, however, removes it at once from the Scutelleroides, for no portion of the inner or apical margins of the corium is covered by the scutellum: whilst in all Scutelleroides the inner margin, with a portion of the apical one, passes under the edge of the scutellum.

The species described by me in the British Museum Catalogue, under the name of Ednus obscurus, inhabits the Philippine Islands and Java; the present species is from Hong Kong.

AEdnus ventralis, n. s. (PI. I. fig. 3.)

Æ. fusco-griseus, nigro-punctatissimus; abdominis disco nigro ; antennis testaceis, apice fuscescentibus; pedibus luteis, nigropunctatis. 8 s .

Long. lin. 3-3 $(\mathrm{m} .0 .006)$.

Hab. "Hong Kong." In my own collection.

Ovate, rather convex, pale greyish brown, very thickly and finely punctured with black. Head rather small, very minutely punctured with black both above and beneath. Eyes pale; ocelli yellowish. Antennæ slender, rather sparingly clothed with short hairs ; three first joints testaceous, fourth joint pale brown, with the base testaceous; fifth joint pale brown. Rostrum yellow. Pronotum very thickly and finely punctured with black, with the punctures more distant on a slightly impressed space, which crosses the disc about the middle, forming a pale transverse band; immediately in front of this impressed space are four small pale tubercles. Scutellum very large, reaching very nearly to the apex of the body, constricted a little before the middle; very thickly and finely punctured with black, more thickly punctured and somewhat rugose towards the base, where there is a small smooth whitish point on each side within the basal angles; the basal angles themselves black. Breast rather darker than the upper surface, very thickly and finely punctured with black. Legs yellow; thighs with numerous black or brown points, the anterior pair with a double row of small black spines on the lower surface; tibiæ with a few brown points, and with a few minute bristles along the edges. Elytra with the coriaceous portion rather less thickly punctured than the thorax and scutellum ; membrane transparent, colourless. Wings semitransparent, iridescent. Abdomen beneath deep shining black, slightly brassy, very thickly and finely punctured; the margins pale griseous, 
thickly and finely punctured with black; the edges with small black spots at the junctions of the segments.

Fam. HALYDIDÆ.

Genus Dinidor, Lap.

Dinidor lineatus, n. s. (Pl. I. fig. 4.)

D. testaceus, fusco-punctatus, pilosus ; thorace lineis 4 nigris; scutello elytrisque nigro- vel fusco-lineatis; antennarum articulis 1 et 2 testaceis, subtus et secundo apice nigris, 3 et 4 basi albis, apice nigris. $q$.

Long. lin. 8 ( $\mathrm{m} .0 .017)$.

Hab. in Americæ meridionalis provincia "Parà " dicta. In my own collection.

Ovate, testaceous. Head bifid in front; above rather thickly and coarsely punctured with brown, pilose, with a brown line down each side of the central lobe and two others on the vertex; beneath smooth, with a few brown punctures, pilose; antenniferous tubercles black above. Eyes brown; ocelli reddish. Antennæ with the basal joint greyish testaceous above, black beneath and on the sides; second joint above greyish testaceous, with the apex black, beneath black; first and second joints clothed with rather long slender hairs ; third and fourth joints yellowish white at the base, black at the apex, with the extreme tip of the fourth joint whitish, both joints clothed with short fine hairs. Rostrum yellowish testaceous, with the tip black. Pronotum hexagonal, with the posterolateral margins shortest, the antero-lateral margins slightly waved and fringed with longish hairs, the lateral angles rather acute but not prominent; irregularly punctured with brown, but with two rows of the punctures so placed as to enclose between them a central longitudinal impunctate line; the disc with four black longitudinal lines, of which the two central run from immediately behind the ocelli, becoming more distant towards the posterior margin; the two lateral, which are slightly waved, run from a little within the anterior angles to the postero-lateral margins a little way from the posterior angles. Scutellum rather long, somewhat pointed at the apex, pilose, punctured with brown, more coarsely at the base, more finely towards the apex, with a blackish line on each side at the base, within each basal angle, and two black lines on the dise neither reaching the base nor the apex, and enclosing between them a slight flat ridge, which is on a level with the elevated 
basal portion. Breast somewhat fulvous, punctured with brown, with an indistinct blackish band on each side close to the lateral margin; sternum deeply furrowed, impunctate. Legs fulvous, very pilose; claws tipped with black. Elytra with the coriaceous portion testaceous, not very thickly punctured with brown, the punctures of the disc finer than those of the margins; the disc with a brown line along the course of the submarginal nervure, and an indistinct line of the same colour within this, running from about the middle of the disc to the middle of the apical margin; membrane brown, with white nervures. Margins of the abdomen testaceous, punctured with brown, and fringed like the thorax with hairs, with a black mark at the junction of each segment. Abdomen beneath fulvous, pilose, punctured with brown on the sides, the disc impunctate; with a band formed of confluent black points on each side close to the lateral margin; apical portion of the basal vulvar plates black.

\section{Family PENTATOMIDÆ.}

\section{Genus Tropicoris, Hahn.}

This genus, established by Hahn for the reception of the Cimex rufipes, Linn, has hitherto contained only that species. It is placed among the Rhaphigastrides by Amyot and Serville, the typical species having a very minute spine at the base of the abdomen, but it must be considered rather as a transition from that group to the true Pentatomides, - the species which I have now to describe not possessing the slightest trace of a ventral spine, although in most other respects agreeing precisely with the T. rufipes.

\section{Tropicoris latus, n. s. (Pl. I. fig. 5.)}

T. supra griseo-fuscus, nigro-punctatus, subtus cum pedibus fulvus; capite, thorace antice, abdominisque marginibus nigro-æneis, his albido-maculatis; puncto albido in singulo elytro. $q$.

Long. lin. 6 (0.012).

Hab. in Brasilia? In my own collection.

Broadly ovate, above brown, very thickly and finely punctured with black. Head above blackish, tinged with brassy green, with the tip of the central lobe orange; the lateral lobes in this specimen scarcely meet in front of the central lobe; beneath pale fulvous, with a few scattered punctures. Eyes brown; ocelli reddish. 
Antennæ with the basal joint yellow; second joint whitish, with a blackish line on each side; third joint a little shorter than the second, pitchy, with the apex black, the base white; fourth joint longest, black, with the base white; fifth joint wanting; third and fourth joints sparingly clothed with fine hairs. Rostrum reaching the base of the abdomen, pale fulvous, with the apex and a line down the suture pitchy black; labrum with a slender black line down the middle. Pronotum transverse, with the lateral angles produced into large truncated processes, having their anterior angles rounded off, the posterior acute; antero-lateral margins faintly denticulated; disc brown, very thickly and finely punctured with black, and with two minute whitish points towards the anterior margin; anterior and antero-lateral margins and lateral processes blackish, tinged with brassy green. Scutellum triangular, nearly equilateral, brown, very thickly and finely punctured with black, especially towards the base, and with a minute whitish point in the centre of the base; apex concolorous. Elytra with the coriaceous portion brown, thickly and finely punctured with black, especially along the outer margin, the basal portion of which is brassy green; the disc with a small whitish point a little behind the middle; membrane brown, margins of the abdomen black, tinged with brassy green, thickly and rather coarsely punctured, and with a small whitish spot in the middle of the margin of each segment. Thorax beneath pale fulvous, thickly punctured; the punctures near the insertions of the legs and all those on the metathorax blackish or brown; metathorax with a small, raised, dull space, marked with five or six distinct wrinkles on each side, close to the orifice of the odoriferous apparatus. Legs fulvous, with a few pale reddish brown points. Abdomen beneath fulvous, thickly and very finely punctured, with the central line of the disc smooth.

\section{Genus Amphaces, Dall.}

This genus, proposed by myself, at p. 295 of the Catalogue of Hemiptera in the British Museum, is nearly allied to Acanthosoma, but is readily distinguished from it by the slight development here attained by the sternal keel and ventral spine. In the work above quoted I have described two species, which closely resemble each other in form and colour, differing principally in size and the relative proportions of the joints of the antennæ. The species which I have now to describe, and of which a single specimen exists in the collection of this Society, is of a much more elongated form than either of these, and is entirely of a pale green colour. Like the other species it is from Australia. 


\section{Amphaces virescens, n. s. (Pl. I. fig. 6.)}

A. elongato-ovata, virescens, punctata; oculis fusco-rufis, ocellis rufis; antennarum articulis 4 to. et 5 to. fulvescentibus; rostro apice nigro. $\delta$.

Long. lin. $6 \frac{1}{4}$ (m. 0.013), hemelytrorum membrana inclusa.

$\mathrm{Hab}$ in Australia. In the collection of the Entomological Society of London.

Elongate-ovate, pale green. Head above minutely punctured and very finely wrinkled transversely; beneath finely wrinkled near the eyes, and with the disc minutely punctured. Eyes reddish brown : ocelli red. Antennæ with the three basal joints pale green, clothed, the basal joint very sparingly, the second and third more plentifully, with short hairs; basal joint rather strongly curved outwards at the apex; fourth and fifth joints fulvous (fifth darkest), very thickly clothed with minute hairs, which render their surface opaque ; fourth joint nearly as long as the second. Rostrum passing the posterior coxæ, longer than in the other species, and with the fourth joint nearly as long as the first; pale greenish yellow, with the tip black. Prothorax above rather finely but not thickly punctured, with a slender smooth line down the centre, and a transverse impunctate patch on each side near the anterior margin; lateral margins very slightly reflexed; disc with a faint transverse furrow across the middle; postero-lateral margins tubercular a little behind the lateral angles; posterior angles very indistinct; prothorax beneath rather faintly punctured; scutellum rather elongate, with the apex acuminated; the disc rather convex, especially towards the base, rather thickly punctured, with a narrow smooth line down the middle; meso- and metathorax beneath nearly impunctate, but with a large common dull patch on each side, surrounding the orifice of the odoriferous apparatus, from which a short curved canal, with raised margins, runs towards the lateral margin of the metathorax; sternal keel whitish. Legs pale; thighs smooth, naked; tibiæ and tarsi rather sparingly clothed with hairs; claws tipped with black. Elytra with the coriaceous portion rather strongly, but not thickly punctured; the lateral margins very slightly reflexed; the membrane whitish, semi-transparent, with the nervures concolorous. Abdomen beneath strongly keeled in the centre, the keel smooth, becoming wider posteriorly so as to include the anal plate; the sides finely wrinkled transversely; basal spine just passing the posterior coxæ 
and touching the posterior point of the sternal keel; anal plate heart-shaped, dusky.

The anal plate in this specimen is raised so as to exhibit the more internal generative organs (fig. $6 a$ ), as is also frequently the case in Acanthosoma; in some species of which genus (A. forfex, $\mathrm{m}$. and elongatum, m.), the crescent-shaped dorsal plate $\left(a^{*}\right)$ attains a very great development. The same thing takes place in several instances in the males of the Urostylida.

\section{Family UROSTYLIDÆ.}

The next insect that I propose to describe belongs to a group which includes insects presenting such singular characters as to render their location in any of the great groups of Hemiptera a matter of some difficulty. Mr. Westwood, who, in 1837, first described three of the species comprised in it, placed them at the end of Mr. Hope's Catalogue of Scutellerida (Scutati, Burm.), and this is probably as nearly as possible their true position. Mr. White, in 1839, in describing (Mag. Nat. Hist. N.S. iii. 543, and Ent. Trans. iii. 94 [1842]) a new species belonging to the group, under the name of Calliprepes Grayii, considers it to be allied to Capsus; and Dr. Herrich Schäffer, in the same year (1839), in describing one of the species described in Hope's Catalogue, under the new name of Typhlocoris semicircularis, regards it also as belonging to the Capsini, in which family, he says, if we do not consider the structure of the elytra as one of its characters, it may form a peculiar group, the character of which would be, "Membrane with several distinct longitudinal nervures; corium without an appendix." As, however, the essential character of the Capsini is derived from the structure of the elytra, it would be manifestly absurd to admit into that family a group which was distinguished by not possessing that character. The error in both these cases arose from the authors referred to possessing only mutilated specimens of species of the genus Urolabida, in which the ocelli are wanting, giving them to a certain extent a more doubtful character than properly belongs to them. In the ninth volume of the Wanzenartigen Insecten, Dr. Herrich Schäffer recurs to his genus Typhlocoris; and whilst quoting as synonymous with it, Mr. Westwood's genus Urostylis, which he must have known had five joints in its antennæ, places it "without doubt" amongst the Coecigeni of Amyot and Serville, in which the number of joints never exceeds four, and from which it diflers in all its characters quite as much as from the Capsini. In the first volume 
of the New Series of the Transactions of this Society (p. 1), in describing a new genus and species (Urochela 4-punctata) belonging to this group, I stated it as my opinion, that the true position of these insects was in the tribe Scutala; and in accordance with that view I have proposed, in the British Museum Catalogue of Hemiptera, the establishment of a distinct family for their reception under the name of Urostylida. The insects included in this family are arranged under three genera, Urochela, Urostylis, and Urolabida, the last of which is distinguished from the other two by the want of ocelli, and includes the Urolabida tenera of Hope, originally described as its type, the Urostylis histrionica of Hope (Typhlocoris semicircularis, H. Sch.), and the Calliprepes Grayii of White, which is distinguished from the other two species by having the female generative organs of the ordinary form, and not produced into large forceps-like processes.

In the other two genera, as in the Scutata generally, the ocelli are present. The first, Urochela, which is distinguished from Urostylis by its stout antennæ, the first joint of which is not much longer than the head, contains three described species, viz., the typical species $U$. 4-punctata, and $U$. bimaculata and obscura described in the Museum Catalogue. The genus Urostylis, distinguished by its very long slender antennæ, of which the basal joint is as long as the head and thorax together, also contains three described species -U. punctigera, Hope, and U. gracilis and pallida of the Museum collection. I have now to add a fourth species to this genus.

\section{Genus Urostylis, Westw.}

\section{Urostylis notulata, n. s.}

U. supra testacea, fusco-punctata; elytrorum corii margine apicali fusco, medio flavo; corpore subtus fulvescenti, abdominis lateribus rufis, margine summo luteo; antennis fuscis, articulo basali testaceo, fusco-punctato. $\$$.

Long. lin. $6-6 \frac{1}{2}$ (m. 0.0125-0.0135).

$\mathrm{Hab}$. in Indiæ orientalis parte boreali. In Mr. Westwood's and my own collection.

Ovate, above pale testaceous. Head rather small, triangular, broader than long; impunctate, faintly wrinkled, with a small oblique pit on each side within the eyes; the apex of the lobes and the whole underside of the head pale yellow. Eyes dark brown; ocelli reddish. Antenniferous tubercles brown. An- 
tennæ clothed with very small whitish hairs; the basal joint testaceous, becoming dusky towards the apex, and covered with very minute brown punctures; second, third and fourth joints brown, the fourth rather paler than the others. Rostrum pale yellow, with the extreme tip black. Pronotum broader than long, trapezoidal, with the anterior angles rounded off; pale testaceous, rather thickly punctured with brown, with an abbreviated longitudinal red line on the centre of the anterior portion; the disc with a faint transverse furrow or impression before the middle; the portion between this furrow and the anterior margin elevated ; prothorax beneath testaceous, finely punctured with brown, and with a pale reddish patch within each antero-lateral angle. Scutellum testaceous, rather thickly punctured with brown. Meso- and metathorax beneath pale fulvous, smooth, impunctate, with a large dull pale brown patch on each side. Legs clothed with fine whitish hairs; thighs yellowish testaceous, covered with fine brown points; tibiæ and tarsi dusky; claws brown. Elytra with the coriaceous portion testaceous, thickly and rather finely punctured; the punctures pale brown, the apical margin brown, with the central portion yellow; membrane transparent, colourless, with a dark brown spot in the inner basal angle. Wings semitransparent, brownish. Abdomen above bright red, shining, very finely wrinkled transversely, with a blackish line on each side within the margins; the margins brownish testaceous, edged with brown. Abdomen beneath with the disc pale fulvous, flat, shining, finely wrinkled transversely, covered with very minute brown points ; the sides red ; the margins testaceous. 


\section{$2 \mathrm{BHL}$ Biodiversity Heritage Library}

1852. "Descriptions of some new Species of Hemipterous Insects belonging to the Tribe Scutata. By W. S. Dallas, Esq., F.L.S." Transactions of the Entomological Society of London 7, 6-17. https://doi.org/10.1111/j.1365-2311.1852.tb02617.x.

View This Item Online: $\underline{\text { https://www.biodiversitylibrary.org/item/51245 }}$

DOI: https://doi.org/10.1111/j.1365-2311.1852.tb02617.x

Permalink: https://www.biodiversitylibrary.org/partpdf/35336

\section{Holding Institution}

Smithsonian Libraries

\section{Sponsored by}

Smithsonian

\section{Copyright \& Reuse}

Copyright Status: Public domain. The BHL considers that this work is no longer under copyright protection.

This document was created from content at the Biodiversity Heritage Library, the world's largest open access digital library for biodiversity literature and archives. Visit BHL at https://www.biodiversitylibrary.org. 